\title{
Serum Free Insulin Concentrations during the Treatment of Diabetic Coma and Precoma with Low Dose Intramuscular Insulin
}

\author{
C. M. Asplin ${ }^{1}$ and M. Hartog \\ University Department of Medicine, Bristol Royal Infirmary, Bristol BS2 8HW, England
}

\begin{abstract}
Summary. Fifty patients in diabetic coma or precoma, 33 of whom had previously received insulin and had circulating insulin antibodies, were studied during treatment with a low-dose intramuscular insulin regime. In the presence of insulin antibodies, serum free insulin was separated from bound insulin by steady-state gel filtration. The initial mean serum free insulin concentration in the group of patients without insulin antibodies was $9 \mathrm{mU} / \mathrm{l}, 1$ to 2 hours after intramuscular therapy it had risen to $22 \mathrm{mU} / 1$, and after 7 to 8 hours to $73 \mathrm{mU} / \mathrm{l}$. The corresponding concentrations for the group with insulin antibodies were 13, 23 and $74 \mathrm{mU} / 1$. No relationship was found between the concentrations of serum free insulin attained and the age of the patients, their initial degree of acidosis, dehydration, and systolic blood pressure, the insulin antibody characteristics of their sera, nor the rate of decline of the blood glucose.
\end{abstract}

Key words: Diabetic coma, precoma, low-dose intramuscular insulin, free insulin, steady-state gel filtration.

Comparison of the concentrations of circulating insulin required for biological activity [1] and those achieved after the administration of different doses of insulin has led to the introduction, in recent years, of low dose insulin treatment for diabetic ketoacidosis [2]. Serum insulin concentrations have previously been reported during such treatment in newly diagnosed patients $[2,3,4]$; however, similar measurements in established diabetics receiving in-

1 In receipt of the Carey Coombs Research Fellowship of the University of Bristol sulin are difficult, because of the almost universal presence of insulin antibodies. In the present study, we have measured and compared circulating free insulin concentrations in known diabetics previously receiving insulin, and in diabetics who had not had prior insulin therapy during treatment for episodes of coma or precoma with a low-dose intramuscular insulin regime.

\section{Patients and Methods}

\section{Patients}

Fifty patients ( 24 male, 26 female) were studied. Thirty-three had previously received treatment with conventional bovine insulin preparations and had circulating anti-insulin antibodies. Seventeen had not previously received insulin and did not have any such antibodies. Details of the two groups are shown in Table 1. Thirty-one were keto-acidotic [5] and 19 were hyperosmolar non-ketotic [6].

All patients were treated, as far as possible, with a standardised regime, in which soluble insulin was given in a dosage of 10 units hourly by intramuscular injection. Initial fluid replacement was with 5 litres, given over 8 hours, of either $154 \mathrm{mmol} / \mathrm{l}$ or $75 \mathrm{mmol} / \mathrm{l}$ saline, depending on the initial plasma osmolality. Potassium replacement was with 20 mmol hourly. Intramuscular insulin was discontinued when the blood glucose had fallen to less than $13 \mathrm{mmol} / \mathrm{l}$, at which time six hourly subcutaneous insulin was begun and the intravenous fluid changed to $222 \mathrm{mmol} / \mathrm{l}$ glucose in $30 \mathrm{mmol} / 1$ saline.

Blood samples were withdrawn before, and between 1 and 2, 3 and 4,5 and 6, and 7 and 8 hours after beginning intramuscular insulin, as near to the half-hour as possible, and $2-3$ hours after the last intramuscular injection. 
Table 1. Details of patients: Group 1: Without insulin antibodies - Group 2: With insulin antibodies

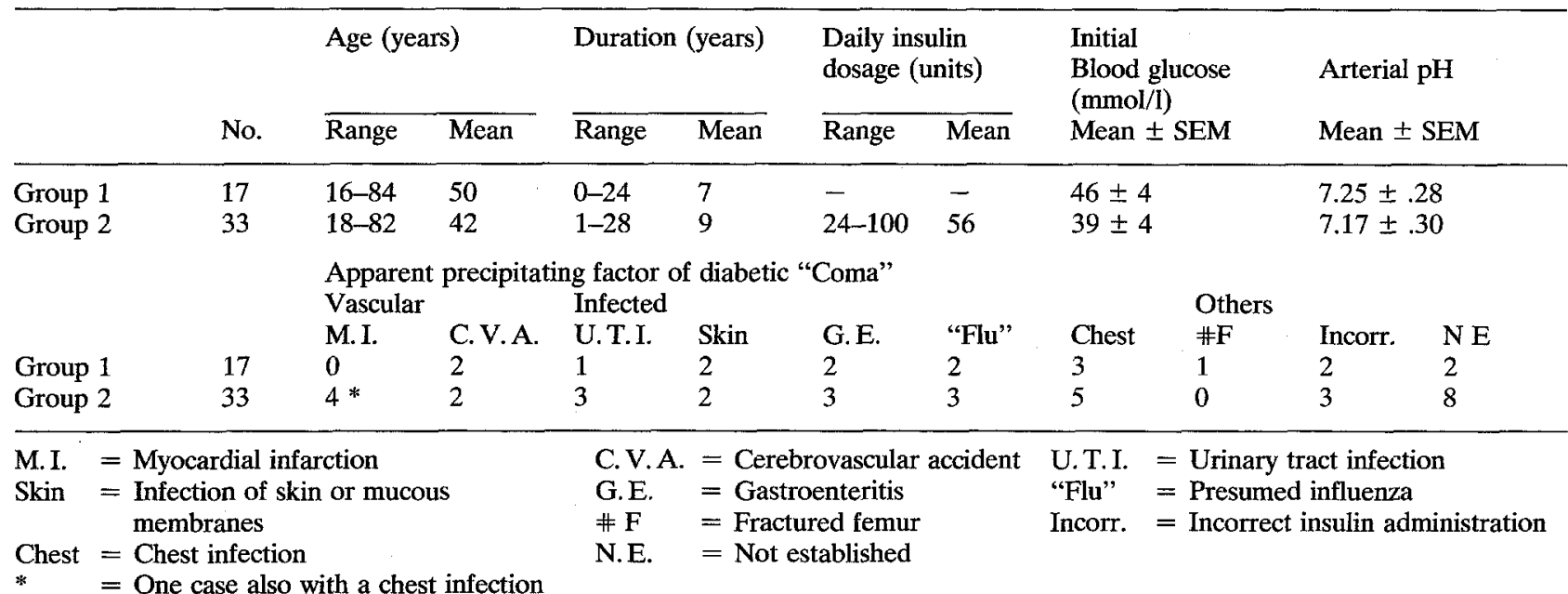

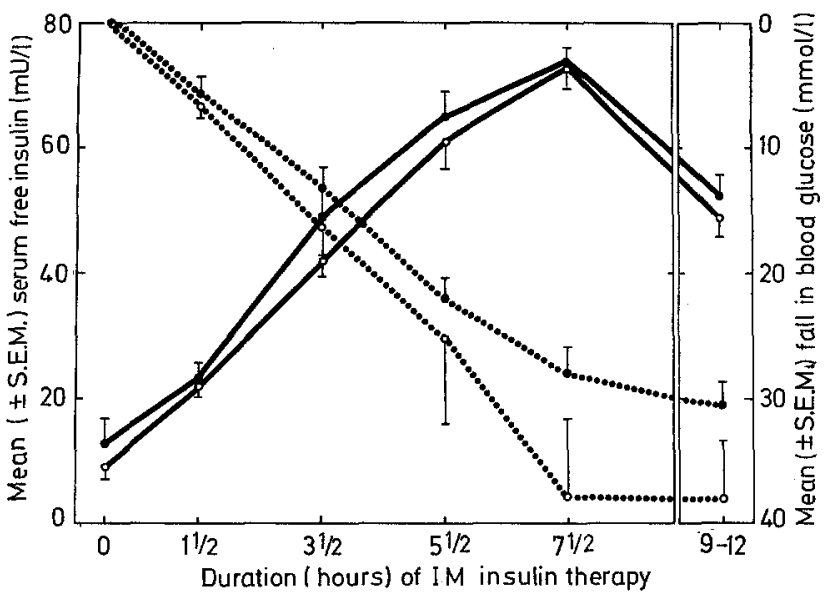

Fig. 1. Mean ( \pm SEM) serum free insulin concentration ( $\mathrm{mU} / \mathrm{I})$ and mean $( \pm$ SEM) fall in blood glucose concentration (mmol/l) in patients with and without insulin antibodies before, during and after low-dose intramuscular insulin therapy.

$$
\begin{array}{cl} 
& \text { Free insulin } \\
\hline \circ & \text { Glucose } \\
\bullet & \text { No antibodies present } \\
& \text { Antibodies present }
\end{array}
$$

\section{Methods}

Blood glucose was measured by autoanalyser employing either glucose oxidase [7] or neocuproine [8]. Plasma urea and electrolytes and arterial $\mathrm{pH}$ were measured by routine chemical laboratory methods.

Serum insulin was measured by radioimmunoassay using charcoal separation [9]. In patients previously treated with insulin serum free insulin was separated from insulin bound to antibody by steadystate gel filtration [10]. This technique was introduced by Burke [11] to study ligand binding in serum and depends on the molecular sieving properties of Sephadex. If a sample of serum is applied to a column packed with Sephadex, the free and bound ligand are separated at the leading edge of the sample, which leads to an initial disturbance of their equilibrium. If, however, the sample is applied to the column continuously, a steady state is eventually established in which the bound ligand equilibrates with the free moiety in the aliquot which preceded it. Free ligand finally emerges from the column separated from bound ligand when sample application is discontinued. Free insulin was assayed directly in the eluates that were protein free. Total insulin was measured after acidification ( $\mathrm{pH} 2$ ) and separation of insulin from antibody protein using the same column and an acid-protein buffer. Insulin antibody characteristics were determined by adding varying amounts of insulin to samples of serum. The bound and free insulin were subsequently separated by steady-state gel filtration and measured by radioimmunoassay. The results were subjected to a Scatchard analysis [12], thereby determining the binding characteristics of the antibodies and assessing binding site heterogeneity.

Differences between various groups of patients selected for analysis were assessed by Student's test. In the case of bound insulin log transformed data was analysed. Unless otherwise stated, no statistically significant differences were found.

\section{Results}

Four patients, 3 of them newly diagnosed diabetics, died during the period of intramuscular insulin therapy; one after 5 hours, and 3 after 6 to 7 hours. Causes of death were cerebral thrombosis in 2 cases, gastro-intestinal haemorrhage and inhalation pneumonia in 1 case and a pulmonary embolus in the fourth. Seven patients, 5 of whom had previous- 
Table 2. Mean ( \pm SEM) serum free insulin (F. I.) concentrations (mU/l) and change in blood glucose (B. G.) (mmol/l) related to \% fall of blood glucose in first 4 hours after insulin treatment commenced

\begin{tabular}{|c|c|c|c|c|c|c|c|c|c|c|c|}
\hline \multirow[t]{2}{*}{$\begin{array}{l}\% \text { Fall in } \\
\text { blood } \\
\text { glucose }\end{array}$} & \multirow{2}{*}{$\begin{array}{l}\text { Initial } \\
\text { FI }\end{array}$} & \multicolumn{2}{|l|}{$1-2 \mathrm{~h}$} & \multicolumn{2}{|l|}{$3-4 h$} & \multicolumn{2}{|l|}{$5-6 \mathrm{~h}$} & \multicolumn{2}{|l|}{$7-8 \mathrm{~h}$} & \multicolumn{2}{|c|}{$\begin{array}{l}2-3 \mathrm{~h} \text { after } \\
\text { discontinuing } \\
\text { I. M. insulin }\end{array}$} \\
\hline & & FI & $\mathrm{BG}^{\mathrm{a}}$ & $\mathrm{FI}$ & $\mathrm{BG}^{\mathrm{a}}$ & FI & $\mathrm{BG}^{\mathrm{a}}$ & FI & BG & FI & BG \\
\hline$>45 \%$ & $\begin{array}{l}12 \pm 2 \\
(12) \\
14+2\end{array}$ & $\begin{array}{l}22 \pm 2 \\
(12) \\
23+2\end{array}$ & $12 \pm 1$ & $\begin{array}{l}47 \pm 4 \\
(12) \\
43+4\end{array}$ & $25 \pm 2$ & $\begin{array}{l}60 \pm 3 \\
(11) \\
63+4\end{array}$ & $32 \pm 3$ & $\begin{array}{l}73 \pm 4 \\
(9) \\
74+3\end{array}$ & $41 \pm 5$ & $\begin{array}{l}51 \pm 3 \\
(10) \\
49+5\end{array}$ & $42 \pm 4$ \\
\hline$<25 \%$ & $\begin{array}{l}14 \pm 2 \\
\text { (9) }\end{array}$ & (9) & $3 \pm 1$ & (9) & $7 \pm 1$ & (9) & $15 \pm 3$ & (7) & $28 \pm 5$ & (8) & $29 \pm 6$ \\
\hline
\end{tabular}

( ) = No. of subjects

a Statistically significant difference between the 2 groups of subjects: $0.001>p>0.01$

Table 3. Mean ( \pm SEM) serum free insulin (F.I.) concentrations (mU/l) and change in blood glucose (B. G.) (mmol/l) related to initial systolic B.P. (mmHg) and arterial $\mathrm{pH}$

\begin{tabular}{|c|c|c|c|c|c|c|c|c|c|c|c|}
\hline & \multirow{2}{*}{$\begin{array}{l}\text { Initial } \\
\text { F.I. }\end{array}$} & \multicolumn{2}{|l|}{$1-2 \mathrm{~h}$} & \multicolumn{2}{|l|}{$3-4 h$} & \multicolumn{2}{|l|}{$5-6 h$} & \multicolumn{2}{|l|}{$7-8 \mathrm{~h}$} & \multicolumn{2}{|c|}{$\begin{array}{l}2-3 \mathrm{~h} \text { after } \\
\text { discontinuing I. M. } \\
\text { Insulin }\end{array}$} \\
\hline & & F.I. & B.G. & F.I. & B.G. & F.I. & B.G. & F.I. & B.G. & F.I. & B.G. \\
\hline B.P. $>125$ & $\begin{array}{l}14 \pm 3 \\
(12)\end{array}$ & $\begin{array}{l}24 \pm 3 \\
(12)\end{array}$ & $8 \pm 2$ & $\begin{array}{l}46 \pm 5 \\
(12)\end{array}$ & $17 \pm 3$ & $\begin{array}{l}60 \pm 3 \\
(12)\end{array}$ & $25 \pm 3$ & $\begin{array}{l}74 \pm 3 \\
(10)\end{array}$ & $34 \pm 5$ & $\begin{array}{l}50 \pm 3 \\
(12)\end{array}$ & $37 \pm 4$ \\
\hline B.P. $<80$ & $\begin{array}{l}12 \pm 2 \\
(12) \\
15 \pm 1\end{array}$ & $\begin{array}{l}22 \pm 2 \\
(12) \\
25 \pm 2\end{array}$ & $9 \pm 2$ & $\begin{array}{l}48 \pm 2 \\
(12) \\
50 \pm 3\end{array}$ & $18 \pm 3$ & $\begin{array}{l}65 \pm 3 \\
(11) \\
66 \pm 3\end{array}$ & $27 \pm 3$ & $\begin{array}{l}76 \pm 3 \\
(8) \\
77 \pm 2\end{array}$ & $31 \pm 4$ & $\begin{array}{l}53 \pm 3 \\
(9) \\
57 \pm 3\end{array}$ & $36 \pm 4$ \\
\hline $\mathrm{pH}>7.30$ & $\begin{array}{l}(13) \\
10 \pm 2\end{array}$ & $\begin{array}{l}(13) \\
20 \pm 1\end{array}$ & $9 \pm 1$ & $\begin{array}{l}(13) \\
43 \pm 3\end{array}$ & $18 \pm 2$ & $\begin{array}{l}(11) \\
61 \pm 4\end{array}$ & $29 \pm 3$ & $\begin{array}{l}(9) \\
73 \pm 5\end{array}$ & $40 \pm 5$ & $\begin{array}{l}(10) \\
54 \pm 4\end{array}$ & $44 \pm 5$ \\
\hline $\mathrm{pH}<7.10$ & (11) & (11) & $6 \pm 1$ & (11) & $18 \pm 2$ & (11) & $26 \pm 3$ & (9) & $33 \pm 4$ & (11) & $37 \pm 4$ \\
\hline
\end{tabular}

$(\quad)$ No. of subjects

ly been treated with insulin, were transferred to subcutaneous insulin therapy after 5 to 6 hours and the remainder after 7 to 8 hours.

Mean serum free insulin and mean fall in blood glucose concentrations in patients with and without insulin antibodies are shown in Figure 1. Similar concentrations of free insulin and falls of blood glucose were found in the two groups. The overall mean fall in blood glucose 4 hours after starting intramuscular insulin therapy was $35 \%$. Comparison of free insulin concentrations in two groups of patients in whom the blood glucose fell relatively rapidly or slowly, showed that the serum free insulin concentrations attained did not appear to influence the rate of decline of blood glucose (Table 2).

No relationship was found between the concentrations of serum free insulin found during treatment and the age of the patient. Thus 13 patients under 30 years old had initial mean ( \pm SEM) serum free insulin concentrations (mU/l) of $5( \pm 2)$ rising to $44( \pm 2) 3$ to 4 hours after beginning treatment,
$70( \pm 4)$ after 7 to 8 hours, and $51( \pm 3) 2$ to 3 hours after discontinuing intramuscular insulin. The corresponding figures for the 16 patients studied who were over 65 years were $17( \pm 1), 48$ $( \pm 3), 77( \pm 2)$ and $53( \pm 3) \mathrm{mU} / \mathrm{l}$. The presence or absence of insulin antibodies in the serum of these groups of patients did not apparently influence the concentrations of free insulin attained. Similarly, patients with extremes of either the initial systolic blood pressure or arterial $\mathrm{pH}$ achieved comparable concentrations of serum free insulin during treatment (Table 3). The mean ( \pm SEM) serum free insulin concentration $(\mathrm{mU} / \mathrm{l})$ for a group of 14 patients whose initial calculated plasma osmolality was greater than $345 \mathrm{mosm} / \mathrm{l}$ was $16( \pm 2)$ before the insulin therapy, rising after 3 to 4 hours to $45( \pm 2)$, after 7 to 8 hours to $77( \pm 3$ ), and declining 2 to 3 hours after discontinuing intramuscular insulin to $51( \pm 3)$. The corresponding values for a group of 13 patients whose initial calculated plasma osmolality was less than $310 \mathrm{mosm} / \mathrm{l}$ were $10( \pm 2), 44( \pm$ 


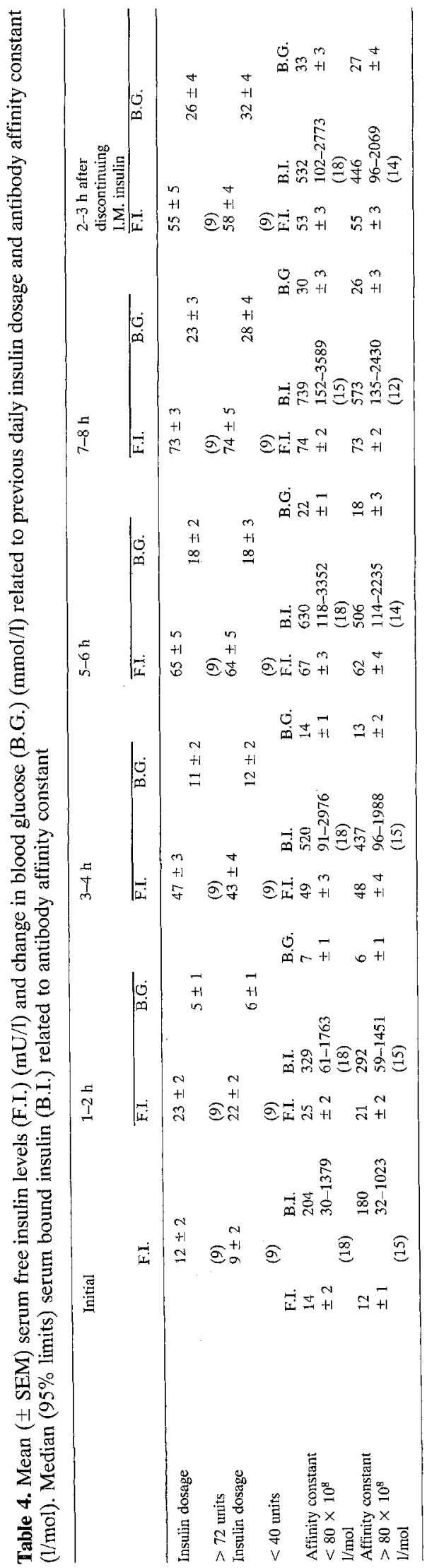

3), $72( \pm 2)$ and $48( \pm 3) \mathrm{mU} / \mathrm{l}$. Again the presence of insulin antibodies did not affect the concentrations of serum free insulin attained. The presence or absence of infection also did not appear to influence the concentrations of serum free insulin found during treatment. In the non-infected groups of patients, the mean $( \pm$ SEM) serum free insulin concentrations $(\mathrm{mU} / 1)$ were, initially $13( \pm 1) 1$ to 2 hours after starting intramuscular insulin therapy, 23 ( \pm 1 ) after 3 to 4 hours, 47 ( \pm 3 ) after 5 to 6 hours, $64( \pm 3)$ and after 7 to 8 hours $74( \pm 2)$. Two to three hours after the last intramuscular injection the mean concentration was $55( \pm 3)$. The corresponding values for the infected patients were $10( \pm 1), 22( \pm 1), 45( \pm 2), 63( \pm 3), 73( \pm 2)$ and $51( \pm 2) \mathrm{mU} / \mathrm{l}$. The mean $( \pm$ SEM) fall in blood glucose $(\mathrm{mmol} / \mathrm{l})$ concentrations for the noninfected group after beginning insulin treatment was $7( \pm 1)$ after 1 to 2 hours, $14( \pm 2)$ after 3 to 4 hours, $21( \pm 2)$ after 5 to 6 hours, and $31( \pm 3)$ after 7 to 8 hours, and the mean fall was $33( \pm 2$ ) 2 to 3 hours after the last intramuscular injection. The corresponding values for the infected group were $7( \pm 1), 15( \pm 2), 24( \pm 2), 31( \pm 3)$ and 34 $( \pm 3) \mathrm{mmol} / \mathrm{l}$. The presence or absence of insulin antibodies in each of these groups did not appear to affect the concentrations of serum free insulin attained, nor the falls in blood glucose.

The Scatchard plots of the binding characteristics of sera from the patients with insulin antibodies demonstrated evidence for two species of binding site [13]. The serum free insulin concentrations found during treatment were similar when patients with antibodies were separated into two groups on the basis of the affinity constant of the most avid binding site of their antibodies (Table 4). The median (95\% limits) affinity constant for the most avid binding site and total maximum binding capacity for the group with the more avid binding sites was 125 $(47-331) \mathrm{l} / \mathrm{mol} \times 10^{8}$ and $1.54(0.59-4.01) \mathrm{U} / \mathrm{l}$ and for the less avid $21(7-69) 1 / \mathrm{mol} \times 10^{8}$ and 3.68 (1.42-9.55) U/l. The affinity constant for the less avid binding site and the total binding capacity for the two binding sites also did not appear to influence the serum free insulin concentrations attained during treatment. The median bound insulin for these two groups is also shown in Table 4, showing a rise in the bound insulin during intramuscular insulin therapy and a fall after change to subcutaneous insulin.

\section{Discussion}

The method of steady-state gel filtration has been used in the present study to separate circulating free 
insulin from insulin bound to antibody. The method satisfies the criteria suggested for the validation of any technique of separating free from bound ligand $[11,14]$ and has the particular advantage over other methods of measuring serum free insulin (such as ultracentrifugation [15], and ethanol [16] and polyethylene glycol [17] precipitation) of not requiring an extraction step, with its risk of disturbing the equilibrium between bound and free hormone.

Treatment of severe diabetic keto-acidosis by low-dose intramuscular insulin has been found to be effective and convenient [18]. Concern has, however, been expressed that poor absorption of insulin from the injection site in shocked patients, may lead to a delayed response, and the risk of late hypoglycaemia [19]. Others have, therefore, preferred intravenous insulin given either continuously [4] or intermittently [20]. In the present study, however, no evidence of poor absorption from the injection site was found, in that the concentrations of serum free insulin attained during treatment were similar in groups of patients chosen for extremes of initial systolic blood pressure, and of fluid depletion, as assessed by the calculated plasma osmolality. Furthermore, the serum free and bound insulin fell 2 to 3 hours after the last intramuscular injection of insulin in all patients, and no instance of late hypoglycaemia was encountered. The concentrations of free insulin were found to rise gradually during the intramuscular insulin regime of 10 units hourly, so that the highest values were only achieved after several hours of treatment, by which time the blood glucose had usually fallen to less than $13 \mathrm{mmol} / \mathrm{l}$. Thus an insulin regime based upon an initial loading dose, such as an initial dose of 20 units intramuscularly followed by 5 units hourly [5], or an intravenous infusion might be more logical.

There was no clear relationship between the concentrations of serum free insulin found during treatment and the fall of blood glucose. This has previously been reported with a high-dose insulin regime [6] and is not unexpected, in that hyperosmolar and ketoacidotic diabetic coma and precoma are complicated metabolic states, and a number of factors are known to affect the response to treatment. Thus fluid therapy alone has been shown to produce an impressive fall of blood glucose [2]. Furthermore, the circulating levels of free fatty acids and ketone bodies, and hormones such as cortisol, catecholamines and glucagon [6], none of which were measured in the present study, may affect tissue sensitivity to circulating insulin. In this series no clear effect of the presence of an infection was detected, in contrast to the studies of others [2].

The concentrations of serum free insulin found during treatment in the present study were similar in patients previously treated with insulin and who, therefore, had circulating antibodies to the hormone, and in newly diagnosed diabetics. These concentrations were in broad agreement with those found on previous investigations $[2,3,4]$ in newly diagnosed patients and in the appropriate range for the physiological action of the hormone [1]. Furthermore, the binding characteristics of the antibodies to insulin, where present, did not appear to affect the concentrations of serum free insulin achieved; our data do not provide any explanation for this observation. The capacity of these antibodies, together with their speed of action as found in other studies $[21,22]$, would be expected to result in the binding of a proportion of the relatively small doses of administered insulin, as is indeed shown by the rise in the bound fraction of the serum insulin. It may be that with frequent injections of low-doses of insulin a limiting factor in determining levels of circulating free insulin is the very short half life of circulating insulin $[23,24]$. Thus, if the mechanisms for removing free insulin from the serum are similar in patients with and without circulating antibodies to insulin, and if the rate of its removal is rapid as compared with the rates of association and dissociation of insulin with its antibody, then with frequent injections, comparable concentrations of serum free insulin are likely to be found in such patients.

It is interesting to note that the concentration of bound insulin increased in parallel with the concentration of free insulin. The increase tended to be greater in the low affinity group. This bound insulin did not appear to contribute to the free plasma insulin pool at the later time periods in that free insulin concentrations remained comparable in all groups.

In conclusion, the results of the present study suggest that a reasonably uniform response, in terms of the concentrations of circulating free insulin attained, can be expected in a wide range of diabetics treated for diabetic coma by low-dose hourly intramuscular injections of insulin.

Acknowledgements. We are most grateful to Dr. D. J. Goldie of the Department of Chemical Pathology, Southmead Hospital, Bristol, for advice and help with the free insulin and antibody measurements, and the physicians and chemical pathologists of the Bristol Royal Infirmary and Southmead Hospital, Bristol, for their co-operation.

\section{References}

1. Sönksen, P.H., Tompkins, C. V., Srivastava, M.C., Nabarro, J.D.N.: Growth-hormone and cortisol responses to insulin infusion in patients with diabetes mellitus. Lancet 1972 II, $155-160$ 
2. Alberti, K. G.M.M., Hockaday, T.D.R., Turner, R.C. Small doses of intramuscular insulin in the treatment of diabetic "coma". Lancet 1973 II, 515-522

3. Semple, P.F., White, C., Manderson, W. G.: Continuous intravenous infusion of small doses of insulin in treatment of diabetic ketoacidosis. Br. Med. J. 1974 I, 694-698

4. Page, M.McB., Alberti, K.G.M.M., Greenwood, R., Gumaa, K.A., Hockaday, T.D. R., Lowry, C., Nabarro, J.D.N., Pyke, D.A., Sönksen, P.H., Watkins, P.J., West, T.E.T.: Treatment of diabetic coma with continuous lowdose infusion of insulin. Br. Med. J. 1974 II, 687-690

5. Alberti, K. G.M. M.: Diabetic ketoacidosis - aspects of management. 10th Symposium on Advanced Medicine, 68-82. London: Pitman Medical Publishing Co. Ltd. 1974

6. Hockaday, T.D. R., Alberti, K.G.M.M.: Diabetic coma. Clin. Endocrinol Metab. 1, 751-780 (1972)

7. Trinder, P.: Determination of blood glucose using an oxidaseperoxidase system with a non-carcinogenic chromogen. J. Clin.. Pathol. 22, 158-161 (1969)

8. Brown, N. E.: Ultra-micro sugar determinations using 2.9-dimethyl 1.10 phenathroline hydrochloride (Neocuproine). Diabetes 10, 60-62 (1961)

9. Albano, D.J.M., Ekins, R.P., Maritz, G., Turner, R. C.: A sensitive, precise, radioimmunoassay of serum insulin relying on charcoal separation of bound and free hormone moieties. Acta Endocrinol (Kbh.) 70, 487-509 (1972)

10. Asplin, C.M., Hartog, M., Goldie, D. J.: Measurement of serum free insulin by steady-state gel filtration. Clin. Chim. Acta 75, 393-399 (1977)

11. Burke, C.W.: Accurate measurement of steroid-protein binding by steady-state gel filtration. Biochim. Biophys. Acta 176, 403-413 (1969)

12. Scatchard, G.: Attraction of protein for small molecules and ions. Ann. N. Y. Acad. Sci. 51, 660-672 (1949)

13. Baxter, R. C., Yue, D.K., Turtle, J. R.: Equilibrium studies of insulin antibodies in diabetic subjects. Clin. Chem. 22, 1089-1094 (1976)

14. Burke, C. W., Lewis, B., Panvelinalla, D., Tabaqchali, S.: The binding of cholic acid and its taurine conjugate to serum proteins. Clin. Chim. Acta 32, 207-214 (1971)

15. Berson, S. A., Yalow, R.S.: Immunoassay of plasma insulin. Ciba Coll. Endocrinol. 41, 182-211 (1962)

16. Heding, L. G.: Determination of free and antibody-bound insulin in insulin treated diabetic patients. Horm. Metab. Res. 1, 145-146 (1969)

17. Nakagawa, S., Nakayama, H., Sasaki, T., Yoshino, K., Yu, Y. Y., Shinozaki, K., Aoki, S., Mashimo, K.: A simple method for the determination of serum free insulin levels in insulin-treated patients. Diabetes 22, 590-600 (1973)

18. Moseley, J.: Diabetic crises in children treated with small doses of intramuscular insulin. Br. Med. J. 1975 I, 59-61

19. Soler, N. G., FitzGerald, M. G., Wright, A.D., Malins, J.M.: Comparative study of different insulin regimens in management of diabetic ketoacidosis. Lancet 1975 II, 1221-1224

20. Clumeck, N., De Troyer, A., Naeije, R., Somers, G., Smekens, L., Balasse, E.O.: Treatment of diabetic coma with small intravenous insulin boluses. Br. Med. J. 1976 II, 394-396

21. Dixon, K.: Measurement of antibodies to insulin in serum. Clin. Chem. 20, 1275-1281 (1974)

22. Berson, S. A., Yalow, R.S.: Quantitative aspects of the reaction between insulin and insulin-binding antibody. J. Clin. Invest. 58, 1996-2016 (1959)

23. Ørskov, H., Christensen, N. J.: Disappearance rate of exogenous human insulin. Lancet 1966 II, 701

24. Samols, E., Marks, V.: Disappearance rate of endogenous insulin in man. Lancet 1966 II, 700

Received: November 12, 1976, and in revised form: April 26, 1977

Dr. C. M. Asplin

Department of Medicine

Bristol Royal Infirmary

Bristol BS2 8HW

Great Britain 